\title{
The Influence of Systemic Racism on Quarter- Life Crisis in The Autobiography of Malcolm $X$ (As Told to Alex Haley)
}

\author{
Bhakti Satrio Nugroho ${ }^{1}$, Dwi Septi Aryani ${ }^{2}$
}

\author{
${ }^{1}$ American Studies Master's Program, Universitas Gadjah Mada, Indonesia \\ ${ }^{2}$ Professional Psychology Master's Program, University of Sumatera Utara, Indonesia
}

\begin{abstract}
This paper aims to analyze the influence of systemic racism on quarter-life crisis, experienced by Malcolm X, as seen in The Autobiography of Malcolm X (As Told to Alex Haley). The emphasis of this research is to find the relation between racial segregation in American society and its influence on quarter-life crisis, which is a psychological crisis of uncertainty, self-insecurity and identity confusion, occurs during emerging adulthood period. Therefore, by applying a qualitative method, this research works under Post-Nationalist American Studies and psychosocial approach as an integrated paradigm which accommodates the inter-disciplinary aspects of "self and society". The analysis shows that racial segregation, in the field of education and job occupation, is a form of systemic racism which influences Malcolm X's mental wellness as a young African-American. Racial segregation, in this case, is "a function of blocked opportunities" which disallows young African-Americans to develop their own competencies and to achieve their "American Dream". In the development of his quarter-life crisis, Malcolm X manages to rebuild his new long-term commitment which contributes to the construction of his adult identity as an African-American Muslim activist.
\end{abstract}

Keywords—quarter-life crisis, racism, segregation, Malcolm X.

\section{INTRODUCTION}

Racism in the United States has become the main social issue throughout decades. This polemic issue has been strongly rooted from slavery, which was introduced and developed in the New World by European merchants in 1492 (Finkelman, 2012, p. 105). After the slavery was abolished, its prominent legacy still exists and further affects the development of culture, society, education, economics and even politics in the United States. The complexity of this racial issue has deeply become part of American identity which has already integrated in almost every layer of American social system.

In understanding of American society and its racial issue, The Autobiography of Malcolm X (As Told to Alex Haley) offers a reality of racial discrimination that appeared prior to Civil Rights Era. It is often called in American history as period of racial segregation which separated blacks and whites. It is an "American-style Apartheid" which promoted the racial disparity and inequality by separating both whites and blacks in public spaces such as school, restaurant, public transportation, theater, and public restrooms (Schill \& Wachter, 2001, p. 11). During this racial segregation period, as minority, blacks or AfricanAmericans also suffered from white violence and homicide, such as lynching and other forms of assault, to which some scholars refer as racial genocide (Curthoys \& Docker, 2008, p. 16). Therefore, this intense racial clash between whites and blacks becomes the conspicuous theme that is embedded in Malcolm X's story as an African-American human rights activist during civil rights movement.

Needless to say, The Autobiography of Malcolm X (As Told to Alex Haley) has been studied extensively both in historical and literary context. Laura Dubek in her essay entitled "The Autobiography of Malcolm X and the African American Quest for Freedom and Literacy" explains that, in historical perspective, Malcolm X remains as an influential figure today as he was during the civil rights movement (2014, p. 196). His progressive approach in civil rights movement, compared to Martin Luther King Jr., has inspired his young generation in achieving racial equality which continues until today. Furthermore, in 
literary perspective, The Autobiography of Malcolm X (As Told to Alex Haley) can be categorized as non-fiction genre which provides an alternative discussion in literary studies. This genre implies "something not fictionalized or "made-up," which fluidizes the boundaries between fiction and non-fiction (Dubek, 2014, p. 198). In other words, as a narrative, this autobiography provides social and historical aspects, as well as literary aspects, that can be studied in understanding the problematic racial issue in American society prior to Civil Rights Era.

This research utilizes The Autobiography of Malcolm X (As Told to Alex Haley) as both literary and historical text which offers a rich picture of society that seems to be disintegrated due to racial prejudice and stereotype toward each other. It aims to elaborate and analyze the influence of systemic racism on quarter-life crisis by using psychosocial approach, under Post-Nationalist American Studies. In conducting an in-depth analysis, this research utilizes two main theories: systemic racism and quarter-life crisis to answer research questions of how does systemic racism and quarter-life crisis exist and how does systemic racism influence quarter-life crisis of Malcolm $\mathrm{X}$ as depicted in this narrative. As research limitation, this research only focuses on Malcolm X's psychological crisis of finding his identity as a young African-American during his emerging adulthood period. It focuses on race-based maltreatment aspect which further impacts his quarter-life crisis.

\section{THEORETICAL FRAMEWORK}

This research is under Post-Nationalist American Studies which also utilizes psychosocial approach. In this context, Post-Nationalist American Studies is a paradigm in American Studies which concerns with cross-cultural communication, race and gender, global and local identities, and the complex tensions between symbolic and political economies. The discussion of this paradigm is around the complex issues in American society which may deal with ethnic, race, gender and women's studies and other minor issues in the United States (Rowe, 2000, p. 23). Thus, under Post-Nationalist American Studies, this research no longer celebrates of Americanization nor American exceptionalism, but instead questioning and criticizing the local issues within American society which may have been overshadowed by the cosmetic appearance of American exceptionalism.

Meanwhile, psychosocial approach is an inter-discipline of psychology and sociology that focuses on the influence of psychological factors and the surrounding social environment toward individual's physical and mental wellness (Woodward, 2015, p. 3-4). Therefore, there are relations between the social and the psychic aspects which become the scope of analysis (Woodward, 2015, p. 5). Therefore, this approach is conducted in medical as well as social science field. As University of East London (UEL) further describes that, psychosocial studies,

"offers new ways of exploring the relationships between individuals and their society, encompassing both the individual focus of psychology and the broader cultural and historical concerns of sociology... [and providing] a unique opportunity to study a "socially-aware" psychology alongside an "individual-sensitive"sociology". (in Frosh, 2003, p. 1550)

It means that this approach tries to connect between individuals and their society. As an intersection of both psychology and sociology, the discussion that surrounded psychosocial approach involves the notable notion of "nature vs. nurture" which can be useful to understand human aspects in the field of both psychology and social science. It construes everyday problem which is faced by a certain individual within his/her social environment.

Furthermore, in this context, Post-Nationalist American Studies and psychosocial approach consist of interdisciplinary scope that connects and completes one to another. In this research, the combination of both is an integrated paradigm which accommodates the interdisciplinary aspects of "self and society". Therefore, it creates a larger scope in the discussion. Thus, under PostNationalist American Studies and psychosocial approach, this research utilizes two main theories: systemic racism and quarter-life crises, which aim to analyze the influence of systemic racism on quarter-life crisis as seen in this narrative.

\subsection{Systemic Racism}

In definition, systemic racism, or also known as institutionalized racism, is a "material, social, and ideological reality that is well-embedded in major US institutions" (Feagin, 2006, p. 2). It is a form of racial oppression which deeply rooted within societal levels in American society such as group relations, institutions, organizations, and power structures (Feagin \& Elias, 2013, p. 936). This racial oppression is fundamentally materialistic in which it is applied to limit some racial group for achieving equal rights as citizen. It puts one minority racial group hierarchically under the majority racial group regarding to power and resources within asymmetrical system. Thus, as Feagin and Elias further say, systemic racism has produced racial treatments, which is unequal in American societal institutions including 
education, health, medical, and welfare. In the context of American social system, the systemic racism perpetuates the white domination over African-American in postslavery period, especially prior to Civil Rights Era, which also still becomes an endless discussion until today.

\subsection{Quarter-Life Crisis}

Quarter-life crisis refers to a period of psychological crisis which includes identity confusion, job suitability, insecurity, pressure (from family or others), relationship and other psychological and social factors (Robbins \& Wilner 2017, 3). In other words, this psychological crisis relies on both personal and social elements, which influence on an individual's mental wellness. Furthermore, according to Robert Thouless (in Habibie et al, 2019, p. 135), the factors of quarter-life crisis can be categorized into two: internal and external factor. The internal factor includes personal experience, moral, emotion and affection, and intellectual capability. Meanwhile, the external factor includes social environment, education, tradition and culture, and everyday demand.

Quarter-life crisis is experienced by emerging adulthood, which is described as a period of identity exploration. The range of this age period is "from (roughly) age 18 to 25", since the crisis during this age mostly focuses on identity exploration (Arnett, 2004, p. 9-10). Previously, Erik Erikson describes this age period as, "eager and willing to fuse their identity with others" $(1977$, p. 237). Thus, for emerging adults who are in the transitional stage from teens to adults, quarter-life crisis involves some phases: locked in, separation/time-out, exploration, and rebuilding (Robinson et al, 2013, p. 30-31). These phases are essential in identifying an individual who experiences quarter-life crisis.

\section{METHOD}

The qualitative method is used for this research since it emphasizes on the researcher's interpretation toward "a social or human problem" as the topic of discussion (Creswell, 2009, p. 3). It focuses on the individual meaning and the importance of rendering the complexity of the discussion, based on the researcher's interpretation. This qualitative research relies on qualitative data, which refer as material things to be investigated (Leedy, 2009, p. 86). Moreover, the technique of data analysis is needed to classify and to arrange the data, based on the research purposes and objectives (Mahsun, 2005, p. 253). It includes (1) data selection, (2) data classification, (3) data interpretation, and (4) data conclusion.

\section{FINDINGS AND DISCUSSION}

The Autobiography of Malcolm X (As Told to Alex Haley) covers a non-fictional reality of racial segregation environment prior to Civil Rights Era, especially in the 1940s and the 1950s. Therefore, to elaborate and to analyze the psychological and sociological aspect within the narrative, the discussion of this research is divided into three subchapters: racial segregation as systemic racism, Malcolm X's quarter-life crisis, and the analysis of the causal relation between both.

\subsection{Racial Segregation as Systemic Racism}

This part attempts to discuss the systemic racism in this narrative which fundamentally relies on racial segregation laws. In The Autobiography of Malcolm X (As Told to Alex Haley), a young Malcolm $X$ lives in racial segregated society which consists of racial discrimination, disparity, violence and prejudice toward each other. In the end of 1940s until the 1950s (prior to Civil Rights Era), American society underwent many societal issues such as white and black homicide, poverty, mob violence, gambling, drug and prostitution business. It is a period where Malcolm X spends his late adolescent life in segregated Boston, Massachusetts and Harlem, New York with the emphasis of how to survive as a drop-out African-American teenager. As it is witnessed by Malcolm $X$ in his autobiography, the finding shows that, besides housing segregation, there are some influential issues within racial segregation laws which affect young African-Americans' future. These issues are highlighted into two points: education and occupation.

In education, American schools prior to Civil Right Era were racially divided, or at least, racially based. This segregation in education was enforced by the law and education policy. Jim Crow laws promoted the limitation of black students in public schools based on Plessy v. Ferguson doctrine in 1896 in which it legalized the separated facilities, including public schools, for blacks and whites (Schauer, 1997, p. 280). In Michigan, where Malcolm X spent his school period, Milliken v. Bradley shows that Plessy v. Ferguson doctrine in education was actually proven as racially imbalanced (Aloud \& Alsulayyim, 2016, p. 6). However, the practice of segregation in learning institutions still continued until its abolishment in 1954 when Brown v. Board of Education case prohibited the separation of public schools for black students (Rothstein, 2013). Needless to say, this discriminative law impacts the experience of black students as minority in white schools, which often become an object of racism. 
In his autobiography, Malcolm X illustrates his school period with the emphasis how many whites or blacks who attend the school. In Lansing, Michigan, for instance, he describes his school period in Pleasant Grove School as racially intense since he and his siblings are the only African-American in the area (X \& Haley, 1973, p. 9). They sometimes involve in the fights with white students over racial matters, "Sometimes the fights would be racial in nature, but they might be about anything" (X \& Haley, 1973 , p. 12). In this school, he and his siblings, Hilda and Philbert, become the minority group which often receives racist treatments from both their friends and teachers. Then, in his new school, Lansing's West Junior High School, he becomes the majority group since this school is located in the heart of black community (X \& Haley, 1973, p. 20). It shows that American schools, prior to Civil Rights Act, are systematically divided which results in racially homogenous schools. They are either categorized as "black schools" or "white schools" which provokes the racial disparity. Statistically speaking, most black students in the United States come from low income families in which large numbers of qualified black students cannot afford a better education (Aloud \& Alsulayyim, 2016, p. $4)$.

As being said, the homogenous school system only exacerbates the racial intense between both communities which can result in more severe form of discriminative treatments toward each other, especially toward young black students as minority. As a result, discrimination against black students, as experienced by Malcolm X, is one of the common problems that black students encountered. The school atmosphere during racial segregation period, as Malcolm X explains, shows a lack of racial toleration which prevents the process of social integration.

In fact, the lessons within the school itself were mostly white-centered, since it prevents black students to have better accomplishment than white students, regarding career. Malcolm X's dream to be a lawyer is one of the obvious examples of this racially discriminative practice. In this context, despite his intelligence in the class, Mr. Ostrowski's advice shattered his dream to be a lawyer in which it is seen as unrealistic for black people (X \& Haley, 1973, p. 38). This colonial belief is imposed to black students in which they become to experience double consciousness regarding their career. As a result, like what happens to Malcolm X, most black school dropouts start becoming less interested in pursuing academic achievements and working as menial workers or criminals such as hustler, pimp, and drug dealer in some big city ghettos (X \& Haley, 1973, p. 111). In other words, the white-centered teachings within the schools only perpetuate black backwardness in segregated American society.

Meanwhile, in occupation, prior to Civil Rights Era, African-Americans were socioeconomically backward compared to whites. Only a few African-Americans were able to become the "upper-class" or "middle-class". In big cities such as New York City and Boston, they mostly lived in ghettos, which are known with inadequate living condition, crime, and gang violence (Hartmann \& Venkatesh, 2002, p. 3). They can only afford menial jobs, such as porter, servants, dishwasher etc., or involve in criminal activities. African-American workers mostly received lower income than whites since they were not protected by anti-discrimination laws (White, 2016). As a result, the numbers of urban poverty increased which mostly dominated by African-American workers who lived in ghettos. Therefore, racial segregation in working space evokes unequal race-based system which definitively determines the occupation or profession, based on people's race.

In his autobiography, as an emerging adult, Malcolm X experiences almost the same experience as other young African-Americans, live in American ghettos, separated from whites and work as menial workers or even criminals. As a school dropout, he is only able to work as menial worker, in order to survive. In fact, he later involves in crimes such as hustler, drug dealer, and burglary in Harlem and Roxbury. In this case, black workers, like Malcolm X, are mostly depended on white people's money. For instance, during World War II, when Harlem is officially closed for white women by the Mayor, black workers begin to slowly lose their profit (X \& Haley, 1973, p. 116). In postcolonial perspective, this black and white society in Harlem, which Malcolm X illustrated, creates a relationship of dependence which positions blacks as white's inferior (Mannoni, 1956, p. 42). In other words, it is a form of dependence and inferiority complex behavior of blacks toward whites, which strengthens white socioeconomic superiority.

Furthermore, this racial disparity in people's occupation creates black urban poverty that leads to the increasing numbers of black crime in American ghettos. In this context, communities that are racially segregated and have high concentrations of poverty, such as Harlem and Roxbury, experience higher levels of crime and violence (Simpson \& Wilson, 1995, p. 37). In fact, Blau and Blau (in Peterson \& Krivo, 1993, p. 1002) argue that this violence crime is an expression of frustration toward the economic inequality. As a result, police brutality and harassment toward black people often occurs during this 
period. As Malcolm X says that narcotics polices often harass suspects and also plant some evidence which is considered as a form of black victimization (X \& Haley, 1973, p. 103-104). Thus, this systemic racism has serious impact on black welfare since African-American job opportunities are limited due to racial segregation laws. The occupation can be determined by race which is both discriminative and unequal for the minority, in this case, black workers.

As it is discussed above, racial segregation in education and occupation, as well as in residential and housing, resembles systemic racism which is embedded in American social system. As Feagin says, it is a form of material, social, and ideological reality that privileges whites in American society (2006, p. 2). This social system socioeconomically avails whites, but, on the other hand, it discourages African-American, to achieve their "American dream". This practice is "a function of blocked opportunities" which disallows certain individuals to develop and to learn about their own competencies. It further evokes self-protective mechanisms that can prevent the individual's willingness to participate (Brondolo et al, 2011, p. 170). The high numbers of African-American school dropouts, during this period, indicate the selfprotective mechanism of African-American in which they become to be less interested in education and decide to pursue menial jobs or become criminals.

This racial segregation is a form of social exclusion, which prevents the minority to integrate with the majority. For African-American, as the excluded racial group, it develops the sense of double consciousness due to the limitation of self-awareness by the society. As being said, for Malcolm X, his social environment is racially discriminative to live in due to this limitation of selfawareness which is systematically constructed by the social environment. This discussion is further explained in the two following subchapters as part of his quarter-life crisis.

\subsection{Malcolm X's Quarter-Life Crisis}

As a continuation of systemic racism, this part attempts to discuss Malcolm X's quarter-life crisis which is considered as an impact of systemic racism prior to Civil Rights Era. The finding highlights two important aspects: Malcolm X's identity exploration as an emerging adult and his quarter-life crisis.

As Arnett states, emerging adulthood is a period of identity exploration that young adults experience from their late teens to their mid-twenties (2004, p. 9-10). In this case, Malcolm X's emerging adulthood period may have come early because he has financially supported himself by working in several menial jobs since his dropout from his junior high school in Mason, Michigan. In his late adolescent, he begins to explore his identity as an AfricanAmerican who lives in segregated American society. Like most African-American teenagers, he becomes an urban hipster who is obsessed with his appearance to look more like white man.

In this context, the conk hairstyle that he adopts resembles his obsession of being a "white-like" black man. It is a form of inferiority complex that is unconsciously experienced by most of African-American teenagers and young adults during that certain period. Moreover, his relationship with a white woman named Sophia, gives him "a status symbol" that a lot of African-Americans want to be. As later realized by Malcolm X that, this obsession and admiration of being white are form of self-degradation which only perpetuates colonial set ups. It is a form of colonial mimicry which is the colonized's desire to reform themselves as "recognizable Other" caused by the inferiority complex (Bhabha, 2004, p. 122). Therefore, instead of self-reformation, it is a self-degradation which later contributes to Malcolm X's identity crisis.

Meanwhile, Malcolm X experiences quarter-life crisis when he involves in various menial and criminal works in Roxbury and Harlem ghettos. As being said, the emphasis of quarter-life crisis is, "individuals relentlessly question their future and how it will follow the events of their past" (Robbins \& Wilner, 2001, p. 2). In this context, during his emerging adulthood period, Malcolm X undergoes many uncertainties involving career stagnation, meaningless romantic relationship, his obsession of being white-like black man, and victimization by the American social environment is bias against blacks. There are personal experiences which influence his quarter-life crisis as part of the driving factor.

The driving factor of Malcolm X's quarter-life crisis are categorized into two: internal and external factor. The internal factor includes his personal experience, moral, emotion, which further continues to his identity confusion. Meanwhile, the external factor is the social environment which is bias against blacks. In this context, systemic racism in education and occupation, which Malcolm X experienced throughout his life, influences his adult identity. During his phase development of quarter-life crisis, as a Muslim convert (mu'allaf), Malcolm X emphasizes his thoughts toward racial inequality, under the name of his new religion. His quarter-life crisis can be elaborated in Robinson's phase of quarter-life crisis which are locked in, separation/time-out, exploration and rebuilding. 
The first phase of Robinson's quarter-life crisis model is locked in, in which an individual experiences the feeling of being trapped by his/her commitment and has no desire to continue it. It will be followed by the termination of that commitment which may be caused by either a "no longer wanted relationship" or a highly pressured or dissatisfying career path (Robinson et al, 2013, p. 30). In other words, it a phase of questioning which further affects his future decision regarding future

Malcolm X's locked in crisis can be seen after his first arrest in Harlem, New York and moved back to Roxbury, Boston, when, as an emerging adult who is involved in various crimes and being a drug addict, he starts questioning his financial instability. In the chapter entitled "Trapped", he illustrates his uncertainty toward his life choice as a criminal who works in various crimes, "Everything was building up, closing in on me. I was trapped in so many cross turns" (X \& Haley, 1973, p. 135). Here is a phase where he begins to question his life choice regarding his future. In the following chapter, when he moves with Shorty, in Roxbury, Malcolm X constantly loses his financial fortune due to his way of life ( $\mathrm{X} \&$ Haley, 1973, p. 142). It is an indication of uncertainty and being trapped which drives him into more severe level of drug addiction.

However, despite his feeling of being trapped, he still involves in crimes, gambling and drug addiction since it is the only way of life that he knows. In fact, he only cares about present, without anticipating his future. His constant loss of money and being broke are an indication of the crisis of uncertainty. In other words, not only he is trapped in the criminal world but he is trapped in the psychological situation regarding his current identity and future. Moreover, by still doing criminal acts, he begins to accept the stereotype of African-American who is mostly known for being criminal, in American social environment due to the high number of black homicide (Peterson, \& Krivo, 1993, p. 1003). Therefore, his social environment and personal emotion are two factors, which lead to his locked in phase of quarter-life crisis.

The second phase of Robinson's quarter-life crisis model is separation/time-out. Separation is a phase when an individual "starts to distance themselves mentally and physically from the commitments that defined" (Robinson et al, 2013, p. 30). Meanwhile, time-out is a phase which occurs during the separation when an individual "takes time away to reflect on their transitional situation, to resolve painful emotions and to develop a new foundation for their adult identity" (Robinson et al, 2013, p. 31). Thus, separation/time-out phase involves an individual's reflection on his/her past and the desire to reform himself/herself regarding future.

In the case of Malcolm X, his phase of separation/time-out can be seen throughout his prison time in Charlestown Prison, and Concord Prison. During this period, Malcolm $\mathrm{X}$ 's quarter-life crisis enters new phase of separation by distancing himself with his past and further reflecting on his transitional situation. Despite being known as antireligious person who condemns any religious topic in the beginning of his prison time, his encounter with Bimbi and Islamic teachings of Nation of Islam from his siblings change his views toward himself and racial issue that occurs in the segregated society where he lives in.

Religiosity, in Malcolm X's case, provides resilience during his quarter-life crisis which later leads to the construction of his adult identity. In fact, Islamic teachings of Nation of Islam are different traditional Sunni Islam, since this religion is propagated as the opposite of white religion (in this case, Christianity), which is intentionally founded to improve the spiritual, mental, social and economic condition of African-Americans in the United States (Nation of Islam, n.d.). Therefore, as a Muslim convert (mu'allaf), the separation phase is a phase of selfrealization which becomes Malcolm X's new foundation to spiritually and intellectually reform himself from his past situation.

In this phase, Malcolm $\mathrm{X}$ begins to distance himself with his criminal-like behaviors which are unethical and immoral. After fully converting to Islam, he begins to practice Islamic teachings of Nation of Islam, such as the prohibition to eat pork and smoke, which he learns from his siblings' letters (X \& Haley, 1973, p. 161). These religious practices are fundamental aspects which obviously against his wild habits as a criminal in Roxbury and Harlem ghettos. Therefore, Malcolm X develops a pattern of separation phase in his quarter-life crisis.

Furthermore, in this phase, Malcolm $\mathrm{X}$ also subsequently develops a sign of time-out which can be seen in his view on black and white issues. He begins to build a new foundation for his adult identity. In this case, besides its religious practice, the doctrine of "The white man is the devil" of Nation of Islam seems to be embedded to Malcolm X's adult identity. He follows the path of Nation of Islam which, as a political movement, condemns the existence of white oppression over blacks in the segregated American society. He further deconstructs American racial society with his critical thoughts, which is an indication of self-awareness improvement. It is a process of decolonizing his mind that fundamentally constructs his adult identity as a human rights activist. 
The third phase of Robinson's quarter-life crisis model is exploration in which "new commitments and goals are proactively tried out and explored" (Robinson et al, 2013, p. 31). At this point, since the new life foundation is built, an individual starts to explore the new commitment within his/her new life. The narrative within The Autobiography of Malcolm X (As Told to Alex Haley) shows that this phase experienced by Malcolm $X$ when he moves to Norfolk Prison Colony where he begins to be actively involved in the intellectual discussion.

Malcolm X's exploration phase includes his conversion to Islam which emphasizes on the exploration of Elijah Muhammad's teaching and its meaning for black people. It also includes self-teaching and brainstorming of knowledge regarding racial issue, black history and civilization that later develop his adult identity. In other words, Malcolm X's self-teaching and brainstorming are regarded as, not only the process of knowledge exploration but also his identity exploration as an African-American, who is socioeconomically oppressed by the whites. Furthermore, in this phase, Malcolm begins to practice his new foundation of life by participating in some intellectual debate and discussion forums with his fellow inmates in Norfolk Prison Colony, in which he develops his oratory skills (X \& Haley, 1973, p. 160). In psychosocial perspective, it is an essential phase in Malcolm X's quarter-life crisis since he starts believing to his new commitments: Islam and black human rights activism. Fundamentally, his adult identity has already been constructed by these new commitments which he strongly believes as the truth.

The last phase of this psychological crisis is rebuilding which is an engagement with new long-term commitments. This period consists of satisfied, enjoyable, passionate, and more reflective feeling toward personal interests, compared with pre-crisis period (Robinson et al, 2013, p. $31)$. In other words, it is a recovery process that involves particular actions toward his new commitments.

Malcolm X experiences this phase of quarter-life crisis since he converts to Islam and is actively involved in religious and intellectual activities in Norfolk Prison Colony. Furthermore, his rebuilding phase can be seen clearly when he is released from the prison and starts actively joining Nation of Islam at Detroit's Temple No. 1. He further rejects his last name, Little, and replaces it with "X" to decolonize his identity from the white oppressors as an African-American, "The Muslim's "X" symbolized the true African family name that he [African-American] never could know" (X \& Haley, 1973, p. 203). It is a manifestation of anti-white doctrine within Islamic teachings of Nation of Islam which also emphasizes his ISSN: 2456-7620 defying stand toward systemic racism in American society. Therefore, there is a formation of self-determination, which can be seen in his passion toward Islam and black movement.

\subsection{The Influence of Systemic Racism on Malcolm X's Quarter-life Crisis}

Needless to say, racial segregation in American social system prior to Civil Rights Era prominently influences the emerging adult's mental wellness, especially for AfricanAmerican who often received racial discrimination. In their research entitled "Racism as a Psychosocial Stressor" (2011), Brondolo, ver Halen, Libby and Pencille explains that "racism can affect cognitive and motivational processes that influence the development of self-regulatory capacities that are necessary for achievement and health" (p. 180). Furthermore, ethnicity-related maltreatment such as racial discrimination experienced either directly or vicariously, is able to become a persistent source of stress (p. 170). It means that systemic racism and other ethnicbased maltreatment can be considered as psychosocial stressor which reduces an individual's motivation and devalues his/her self-concept, which is the way people value and define themselves (Gore \& Cross, 2010, p. 135). Thus, racial segregation as a form of systemic racism has psychological impacts on minority. In this case, personal experience and social environment are able to drive an emerging adult into quarter-life crisis in which an individual may feel ostracized and disoriented because of race or ethnicity.

Malcolm X's mental wellness development during his quarter-life crisis shows that both personal and social environment, play important role as internal and external factor. The internal factor involves his personal experience which is often treated unfairly by white people such as the urban poverty in ghettos and his lawyer-dream discouragement by his schoolteacher. This internal factor is fundamentally formed by the external factor which is systemic racism within American social system, such as in education and occupation. In other words, these factors are strongly related to each other since it mostly deals with racism. Thus, in the case of Malcolm X's, his quarter-life crisis is a result of discriminative social environment which also has already become part of his personal experiences.

However, unlike other young African-Americans who experience the same psychological crisis, Malcolm $\mathrm{X}$ manages to develop his self-determination and selfawareness during his quarter-life crisis and further dedicates himself to a path of activism to uplift of black people from white oppression. His encounters with the 
Islamic teaching of Elijah Muhammad give him new revelation and meaning regarding his future. For Malcolm $\mathrm{X}$, quarter-life crisis is a form of "spiritual and intellectual decolonization" in which he finally explores his selfawareness to further develop his competence, which used to be systematically limited by the social environment because of his race. Thus, black human rights activism is his new long-term commitment which becomes the foundation of his adult identity.

\section{CONCLUSION}

The analysis of The Autobiography of Malcolm X (As Told to Alex Haley) shows that systemic racism, in the form of racial segregation, is able to influence mental wellness, especially for African-Americans who undergo racially discriminative treatments from whites in segregated American society. The existence of Jim Crow laws creates the American social system that avails whites, but, on the other hand, discourages African-Americans to achieve their "American dream". This practice of racial segregation laws is "a function of blocked opportunities" which disallows young African-Americans to develop and to learn about their own competencies. Thus, racial segregation is a form of systemic racism, which is considered as a psychosocial stressor. This psychosocial stressor reduces African-American's motivation toward their future and devalues their self-concept in the middle of American society.

In conclusion, the analysis asserts that systemic racism which is embedded in American social system during racial segregation period is the vital factor of Malcolm X's quarter-life crisis. Malcolm X's quarter-life crisis is mostly influenced by his personal experience and social environment which is able to make him feel ostracized and disoriented because of his race. Therefore, the existing systemic racism within American society prior to Civil Rights Era affects his mental wellness as an emerging adult because he had lived with many social limitations since his child. Furthermore, his quarter-life crisis can be seen as a construction of his adult identity in which he manages to develop his self-determination and selfawareness and further dedicates himself to the path of black human rights activism.

\section{REFERENCES}

[1] Aloud, A., \& Alsulayyim, M. (2016). Discrimination against Black Students. Retrieved September $1^{\text {st }}, 2020$, from http://eric.ed.gov/?id=ED569922
[2] Arnett, J.J. (2004). Emerging Adulthood: The Winding Road From The Late Teens Through The Twenties. New York: Oxford University Press.

[3] Bhabha, H. (2004). The Location of Culture. London and New York: Routledge.

[4] Brondolo, E., ver Halen, B., Libby, D., \& Pencille, M. (2011). "Racism as a Psychosocial Stressor", in R. Contrada and A. Baum (Eds). The Handbook of Stress Science: Biology, Psychology and Health (pp. 167-185). New York: Springer Publishing Company, LLC.

[5] Creswell, J. (2009). Research Design: Qualitative, Quantitative, and Mixed Methods Approaches. Los Angeles: SAGE Publication.

[6] Curthoys, A., \& Docker, J. (2008). "Defining Genocide", in D. Stone (Eds), The Historiography of Genocide (pp. 9-41). New York: Palgrave Macmillan.

[7] Dubek, L. (2014). "The Autobiography of Malcolm Xand the African American Quest for Freedom and Literacy", in P. Phillips (Eds), Prison Narratives from Boethius to Zana (pp. 195-214). New York: Palgrave Macmillan

[8] Erikson, E. (1977). Childhood and Society. London: Paladin Grafton Books.

[9] Feagin, J. R. (2006). Systemic Racism: A Theory of Oppression. New York: Routledge

[10] Feagin, J. R., \& Elias, S. (2013). Rethinking Racial Formation Theory: A Systemic Racism Critique, Ethnic and Racial Studies, 36 (6), 931-960, DOI:10.1080/01419870.2012.669839

[11] Finkelman, P. (2012). The Legal Understanding of Slavery: From the Historical to the Contemporary. United States: Oxford Scholarship.

[12] Frosh, S. (2003). Psychosocial Studies and Psychology: Is a Critical Approach Emerging? Human Relations, 56,15471567, DOI:10.1177/00187267035612005 .

[13] Gore, J., \& Cross, S. (2011). Defining and Measuring SelfConcept Change. Psychological Studies, 56(1), 135-141, DOI: 10.1007/s12646-011-0067-0

[14] Habibie, A., Syakarofath, N, \& Anwar, Z. (2019). Peran Religiusitas Terhadap Quarter-Life Crisis (QLC) Pada Mahasiswa. Gadjah Mada Journal Of Psychology, 5 (2), 129-138, DOI: 10.22146/Gamajop.48948

[15] Hartmann, D., \& Venkatesh, S.A. (2002). American Project: The Rise and Fall of a Modern Ghetto. Harvard: Harvard University Press.

[16] Leedy, P. (1985). Practical Research. New York: Macmillan Publishing Company.

[17] Nation of Islam. (n.d). A Brief History on Origin of Nation of Islam. Retrieved on August 29 ${ }^{\text {th }}$, 2020, from https://www.noi.org/noi-history/

[18] Mahsun. M. (2005). Metode Penelitian Bahasa: Tahapan Strategi, Metode, dan Tekniknya. Jakarta: PT. Raja Grafindo Persada.

[19] Mannoni, O. (1956). Prospero and Caliban: The Psychology of Colonization. Translated by P. Powesland. United Kingdom: Richard Clay and Company, Ltd.

[20] Peterson, R., \& Krivo, L. (1993). Racial Segregation and Black Urban Homicide. Social Forces, 71 (4), 1001-1026 
[21] Robbins, A., \& Wilner, A. (2001). Quarterlife Crisis: The Unique Challenges of Life in Your Twenties. New York: MFJ Books.

[22] Robinson, O., Wright, R.T., \& Smith, J. (2013). The Holistic Phase Model of Early Adult Crisis. Journal of Adult Development, 20 (1), 27-37

[23] Rothstein, R. (2013). For Public Schools, Segregation Then, Segregation Since: Education and The Unfinished March. Retrieved on August 25 ${ }^{\text {th }}$ 2020, from, https://www.epi.org/publication/unfinished-march-publicschool-segregation/

[24] Rowe, J. (2000). Post-Nationalist American Studies. Berkeley: University of California Press.

[25] Sampson, R. J., \& Wilson, W.J. (1995). "Toward a Theory of Race, Crime, and Urban Inequality." in J. Hagan and R. D. Peterson (Eds), Crime and Inequality (pp. 37-54). Stanford: Stanford University Press.

[26] Schauer, F. (1997). Generality and Equality. Law and Philosophy. 16 (3), 97- 279

[27] Schill, M., \& Wachter, S. (2001). Principles to Guide Housing Policy at the Beginning of the Millennium. Cityscape: A journal of Policy Development and Research, $5(2), 5-19$

[28] White, G. (2016). Searching for the Origins of the Racial Wage Disparity in Jim Crow America. Retrieved on August $29^{\text {th }}, \quad 2020, \quad$ from https://www.theatlantic.com/bussiness/archive/2016/02/the -origins-of-the-racial-wage-gap/461892/

[29] Woodward, K. (2015). Psychosocial Studies: An Introduction. New York: Routledge.

[30] X, M., \& Haley, A. (1973). The Autobiography of Malcolm $X$ : as Told to Alex Haley. New York: The Ballantine Publishing Group. 